\title{
"Russian Idea" of F.M. Dostoevsky: from Soilness to Universality
}

\author{
Sergei A. Nizhnikov \\ Peoples' Friendship University of Russia (RUDN University), \\ 6, Miklukho-Maklaya St., Moscow, 117198, Russian Federation, \\ nizhnikov_sa@rudn.ru
}

\begin{abstract}
The author reveals Fyodor Dostoevsky's works main features, his importance for Russian and world philosophy. The researcher analyzes the concept of "Russian Idea" introduced by Dostoyevsky, which became a study subject in Russian philosophy's subsequent history. The polemics that arose regarding the characteristics of Dostoevsky's soilness (Pochvennichestvo) ideology and his interpretation of the Russian Idea in his Pushkin Speech and subsequent comments in A Writer's Diary are unveiled. The author concludes that Dostoevsky overcomes the limitations of soilness and comes to universalism. The universal for him does not have a rootless cosmopolitan character but is born from the national's heyday. Diversity adorns the truth, and national diversity enamels humankind. People's real unity is in that all-human value that is found in the highest examples of each national culture. The truth is not in rootless cosmopolitanism or nationalism - it is in the "golden mean," which, in our opinion, the writer-philosopher sought to express. Dostoevsky wanted to rise above the dispute, to recognize the points of view of the Slavophiles and Westernizers as one-sided, to get out of any particularity to universality.

Keywords: Dostoevsky, Russian idea, soilness, universality, anthropology of hesychasm, all-human, nationality

Funding and Acknowledgement of Sources. The reported study was funded by RFBR, and MOST according to the research project № 20-511-S52002 "Philosophy of Being Human as the Core of Interdisciplinary Research."
\end{abstract}

\section{Article history:}

The article was submitted on 05.08.2020

The article was accepted on 06.10.2020

For citation: Nizhnikov S.A. "Russian Idea" of F.M. Dostoevsky: from Soilness to Universality. RUDN Journal of Philosophy. 2021; 25 (1): 15-24. DOI: 10.22363/2313-23022021-25-1-15-24

The quest for and comprehending of one's own identity is a prerequisite for further developing Russian society. Above all, identity must be comprehended

(C) Nizhnikov S.A., 2021

(c) () This work is licensed under a Creative Commons Attribution 4.0 International License https://creativecommons.org/licenses/by/4.0/ 
based on the material of the national spiritual and intellectual culture. This problem has already been solving in the dispute between Pushkin and Chaadaev, in the disputes between Westernizers and Slavophiles, Gogol and Belinsky, finding its definite result in the Pushkin Speech of F.M. Dostoevsky, who tried to summarize the accumulated debatable and practical experience. "Own" and "borrowed," the European here turned out to be in close and indissoluble intertwining. Dostoevsky wanted to rise above the dispute, to recognize the points of view of the Slavophiles and Westernizers as one-sided, to get out of any particularity to universality.

According to M.A. Maslin, "Russian philosophy in its development shows that the main problems of world philosophy remain pertinent for it, and the Russian thought is open to the world heritage of philosophical traditions." According to the historian of Russian philosophy, "the bearers of the ideas of Russian philosophy were not only Russians but also representatives of other peoples associated with Russia by the community of historical fates..." [1. P. 533]. Thus, Russian philosophical thought in its development was not limited to either territory, nationality, or statehood but was addressed to the universal.

At the same time, B.P. Vysheslavtsev noted that "The main problems of world philosophy are, of course, relevant to Russian philosophy. However, there is a Russian approach to world philosophical problems, a Russian way of experiencing and discussing them. Different nations notice and appreciate different thoughts and feelings in the richness of every great philosopher's content" [2. P. 154]. The stylistic and conceptual features of philosophizing in Old' Rus and Russia took shape in such concepts as cosmism, sobornost, eschatology, historiosophy, Russian Idea, and others [3. P. 150]. They are still far from being studied and require further deepening. Of course, a special place here is occupied by the concept of the Russian Idea. Some philosophemes and metaphysical symbols, which have a pass-through creative influence on the mindset, the ideological composition, and lexical sound of Russian philosophical thought, are not yet marked in it to the extent that they deserve it. Such philosophemes, without a doubt, include the "Russian Idea," about which much is written, but the controversy does not subside.

In Russia, profound thought developed in the direction of metaphysics, when, according to Dostoevsky, "we do not need a million" and "the main thing is the thought to unravel." In his novel The Brothers Karamazov, the writer describes the meeting of two brothers in an inn - Ivan and Alyosha, these "Russian boys": "And what do they talk about in that momentary halt in the tavern? Of the eternal questions, of the existence of God and immortality. And those who do not believe in God talk of socialism or anarchism, of the transformation of all humanity on a new pattern, so that it all comes to the same, they're the same questions turned inside out. And masses, masses of the most original Russian boys do nothing but talk of the eternal questions! Isn't it so?" [4. XIV. P. 213].

Without historical and philosophical analysis of the Russian Idea concept's interpretation, the Russian philosophical identity's image is deprived of both its 
metaphysical content and its expressiveness. Thus, Alexander Schmemann notes in his 1977 report:

\begin{abstract}
"...the dispute about Russia is one of the constant measurements of Russian history. Russia belongs to those countries and nations that argue about themselves. Never a Frenchman wakes up in the morning asking himself what it means to be French. He is fully convinced that being a Frenchman is outstanding. The Russians, on the other hand, tend to be in a constant and intense search for the meaning of their own existence" [5. P. 20].
\end{abstract}

Furthermore, the dispute's founding father is an outstanding Russian writer and thinker, Fyodor Mikhailovich Dostoevsky (1821 - 1881), who first introduced and formulated the Russian Idea concept.

\title{
1. Significance of the Writer-Thinker's Creative Work
}

Fyodor Dostoevsky resigned soon after graduating from an engineering school and devoted himself to literature. A member of political Petrashevsky Circle, he was arrested, sentenced to death, pardoned at the last moment, spent four years in Siberian exile and katorga, returned to the then-capital St Petersburg not broken, but transformed - a luminary of prose and metaphysical thought. Berdyaev stressed "...it is enough to remember Dostoevsky alone to feel what philosophy can and should be in Russia. Russian metaphysics translates Dostoevsky into Russian" [6. P. 91]. According to Georges Florovsky, Dostoevsky "was a brilliant thinkerphilosopher and theologian" [7 P. 68]. In his last novel, he revealed the essence of Orthodoxy in the image of Father Zosima, the Elder. M. Gromov analyzed the heroes of it. For him, "the images of the Karamazov family members have an archetypical meaning." [8. P. 24-25].

We also can speak about Dostoevsky as "a prophet of the Russian revolution" (Berdyaev) because he criticized utopianism that inevitably led to violence in his famous novel Demons: "Dostoevsky discovered that the Russian revolution is a metaphysical and religious phenomenon and not a political and social one... He exposed the force of Russian nihilism and atheism that is quite unique, unlike the Western one" [9. P. 63].

"He who curses his past, is already ours — that is our formula!" — Wrote Dostoevsky [3. XXVI. P. 133]. After him, the concept of nihilism used such thinkers as A. Schopenhauer, K. Hartmann, F. Nietzsche, S. Kierkegaard, O. Spengler, and M. Heidegger. Russian socio-political nihilism has its features associated with revolutionism, the denial of autocracy by Narodniks A.I. Herzen, N.G. Chernyshevsky, N.A. Dobrolyubov, D.I. Pisarev, P.N. Tkachev, as well as anarchists P.A. Kropotkin, M.A. Bakunin, and others. The soilness adherents and conservatives criticized nihilism: among the commentators were M.N. Katkov, F.M. Dostoevsky, N.N. Strakhov (Letters on Nihilism, 1881), N.Ya. Danilevsky, authors of the articles in Vekhi magazine: N.A. Berdyaev, S.N. Bulgakov, S.L. Frank, and others. For instance, Sergei Bulgakov analyzed the pseudoreligious roots of nihilism in Heroism and Asceticism, which Dostoevsky had 
dissected already. He exposed the roots, described the traits, and indicated how to overcome the nihilistic consciousness in Pushkin Speech and in Explanatory Words Concerning the Address on Pushkin Printed Below (1881).

Dostoevsky analyzed the conflicts of moral consciousness (Crime and Punishment, 1866), preached active and sacrificial love: "love a person," "love children, especially," "love animals" [3. XIV. P. 290]. He understood compassion as the main law of social life. Hesychasm deeply influenced Dostoevsky's anthropology. He consciously set out to reveal "the Orthodox view." Simonetta Salvestroni, the Italian investigator, emphasizes: "From this point on, Russian literature finds a writer with a remarkable talent and life experience, able to express the depth and richness of spirituality of the Eastern Church, embodying this spirituality in flesh and blood of its characters" [10. P. 18]. According to Dostoevsky, there is one step from atheism to the faith, however, there is no way forward from a clogged consciousness: it must first be cleansed. At the same time, in a letter to Maikov, the writer confessed regarding the newly conceived novel "The Life of the Great Sinner": "The main question that will be carried out in all parts is the one that I suffered consciously and unconsciously all my life - the existence of God" [3. XXIX, I. P. 117].

A well-known Dostoevsky's thesis says: "A man is a mystery. It must be solved, and if you are solving it throughout your life, then do not say that you have wasted time; I am engaged in this mystery because I want to be human" [3. XXVIII, I. P. 63]. "To change the world in a new way," — he believed, — "we have to make people mentally turn to another road. There will be no brotherhood sooner than you indeed become a brother" [3. XXI. P. 18, 25, 275].

Dostoevsky's creative method is defined as "Christian Realism" [11]. According to O.A. Bogdanova's conclusions, Dostoevsky embodied in his work "cultural potencies and the anthropological ideal of Hesychasm..." [12. P. 295]. Dostoevsky's ideas greatly impacted Vladimir Solovyov, the initiator of the metaphysics of unitotality in Russian philosophy.

\section{Dostoevsky's "Russian Idea": Soilness or Universality?}

According to the famous historian of Russian philosophy V.V. Zenkovsky, Dostoevsky "paved the way for Russian universalism": "We, the Russians, have two homelands: Russia and Western Europe", - so Dostoevsky [3. XXIII. P. 30]. Dostoevsky wanted to speak from ordinary people's point of view, from their truth, to see their unspent forces, that come from the "soil." "We have realized," Dostoevsky wrote in 1861 —, "the necessity of connection... with our native soil, with the people's beginning... for we cannot exist without it: we feel that we have exhausted all our forces in a life separate from the people" [13. P. 147]. He did not like the Narodniks, because he did not looked to the ordinary people from above but strove to understand their faith. Unlike Leo Tolstoy, he did not make himself simple, speaking of the need for public education. 
In his Pushkin Speech (1880), Dostoevsky laid the foundation for developing Russian culture's universality content. However, according to Dostoevsky, it was Alexander Pushkin who kickstarted the process. Like Dostoevsky later, Pushkin evolved "from literary and aesthetic disbelief to religious and moral reflection" [14. P. 9]. Already N. Gogol emphasized: "Pushkin is an extraordinary phenomenon and maybe the only one of the Russian spirit," to which Dostoevsky added "and prophetic." [3. XXVI. P. 149]. Dostoevsky solved the mystery of Pushking's creativity and dedicated to it his famous speech.

Pushkin, by his creativity, tried to help to reach the social solidarity, that was destroyed by Peter the Great's reforms. Dostoevsky wrote: "no Russian writer, neither before nor after, has ever been so intimate and related to his people as Pushkin. They wrote about the people but only as "gentlemen." "In Pushkin, there is something authentically akin to the people..." [3. XXVI. P. 144, 153]. Pushkin's work contributed to Russia's "...the upcoming independent appointment in the family of European nations. Pushkin initiated the development of Russian culture as a universal one. He opened such a trait as "universal sympathy" pointed out that Russian culture seeks to develop spiritual universality:
"Indeed, the purpose of a Russian is undoubtedly all-European and universal.
To become a real Russian, to become quite a Russian, maybe, means only (in the end, it should be emphasized) to become a brother of all people, a universal man, if you want... our destiny is unitotality, acquired not by the sword but by the power of brotherhood and brotherly striving of our people to unite" [3. XXVI. P. 147].

Dostoevsky understood Soilness not just as something from the past but also as the future task. His ideology had to unite the past, present, and build Russia's future: "The concept of soil embraced history and modernity, empirical completeness and metaphysical depth of "people"; thus, the concept of soilness was combined here with the concept of nationality." Unfortunately, Zenkovsky understood Dostoevsky's point of view as a "kind of religious nationalism..." [13. P. 105]. But really, the writer was far from nationalism. His intention was in universal brotherhood: he went from soilness to universality. This is how he wrote: "We anticipate that our activity's nature should be universal to the extreme, that the Russian Idea can be a synthesis of all those ideas that Europe develops with such courage... [3. XVIII. P. 37]. Dostoevsky wanted to overcome the positions and ideologies of Westernizers and Slavophiles because "they have lost a sense of Russian spirit. "

Zenkovsky concluded from these words: "Here is the key to Dostoevsky's famous idea that the Russian people are God-carrying. This belief is the deepest and most creative in Dostoevsky, from which grew his dream of a 'universal' calling for Russia." [13. P. 116-117]. By his understanding in Dostoevsky missionism converted into messianism, and "the combination of soilness and universality created an idyllic view of Russia, easily reborn into narrow nationalism, and reducing all global problems to a Russian problem" [13 P. 119]. But Dostoevsky 
thought about the people metaphysically: "Judge the people not by what they are, but by what they would like to become" [3. XXII. P. 43].

From our point of view, Dostoevsky's "messianism" has nothing to do with nationalism and can belong to any nation that comes out from spiritual. The writer undoubtedly believes that "...if a great nation does not believe that there is one truth in it if it does not believe that it is the only one capable and called to resurrect and save everyone with its truth, then it immediately turns to ethnographic material, not to the great nation" (Shatov's statement in Demons). As V.V. Serbinenko notes, "in Dostoevsky's understanding, Christian messianism meant an opportunity for nations, without renouncing peace and history and preserving their own unique cultural and historical image, at the same time to solve the task of overcoming national isolation and creative perception of other cultural traditions" [15. P. 32].

Nevertheless, Zenkovsky emphasizes that the universal truth was brought too close to Russia by Dostoevsky, and therefore he "remained in the power of Christian naturalism and utopianism." Zenkovsky also discovers an idea of chiliasm in Dostoevsky's creative works. Zenkovsky came to the following conclusion: "in Dostoevsky, soilness prevented him from understanding more deeply and more modestly the role of Russia in history" [13. P. 126].

Arseniy Vladimirovich Gulyga contradicts Zenkovsky's point of view. From his position Dostoevsky as a "world supporter," comes from the "soilness" but goes out and beyond its boundaries: "The stronger the attachment to the native land, the sooner it develops into an understanding that the fate of the motherland is inseparable from the destinies of the world. Hence the characteristic Russian desire to organize the all-European and global affairs" [16. P. 83].

Vladimir Solovyov continued analyzing the concept of "Russian idea" in his 1888 "Russia and the Universal Church" in 1888. However, unlike Dostoevsky, he tilts towards the concept of universality, hence defining his philosophy as an AllUnity. And although Vl. Solovyov wrote about the similarity of his views with Dostoevsky, but this is not so in reality. Only in his last writings, he develops an eschatological position, drawing closer to Dostoevsky (the novel "A Story of Anti-Christ," 1900).

The differences between thinkers are especially striking in the interpretation of the Russian Idea. Unlike Dostoevsky, who proceeds from national culture and rises from it to universal truth, Solovyov looks from above, like a "true" Russian intellectual. For him, everything national is secondary. In fact, he equates the national and the nationalist (the difference between these concepts was fundamental for Dostoevsky). However, in reality, the all-unity of Solovyov ends with the power of the "Catholic high priest." This is, apparently, necessary to overcome "national egoism." Solovyov speaks from an international standpoint, for some reason believing that it is the "high priest" who personifies this demanded ideology of universal reconciliation of everybody with everybody. It can be stated that in Vl. Solovyov's rendition of the Russian Idea, there is nothing Russian - any nation can be brought under it, being previously denationalized. 
In the footsteps of Solovyov will follow Russian "all-union" philosophers, inclined towards liberalism. Slavophilic thinkers will criticize him, and the dispute between Westernizers - Slavophiles will flare up with renewed vigor and already at a new historical stage.

Vl. Solovyov led an active polemic with representatives of late Slavophilism - I.S. Aksakov, N.N. Strakhov, P.E. Astafiev and L.A. Tikhomirov. Opponents criticized his concept for exaggerating an abstract concept of "humankind" at specific nations' expense. In Vl. Solovyov's appeals, e.g., to national self-denial Aksakov, we may witness an attempt to pass off traditional intellectual Westernism as a manifestation of historical truth. It is impossible, Aksakov believed, to serve the highest truth without fulfilling one's duty concerning his compatriots. To serve humanity, it is necessary first to serve the native nation and disclose its strengths and talents. Aksakov wrote that demanding the renunciation of Orthodoxy, Solovyov at the same time did not demand this from other confessions, in fact taking the position of one of them, and not at all preaching a universal non-confessional ideal. N. Strakhov and N. Danilevsky also argued with Solovyov on this issue, defending, as they believed, the idea of an equal unity of humankind.

On the other hand, isn't the universality a kind of superstructure looming over, for instance, national interests? Dostoevsky and Slavophiles considered the universality to be born from the prosperity of the nationality. At the same time, universality is not a mechanical set of specific ideas or works but represents their essence. Multitude adorns truth, and national diversity embellishes humankind (Konstantin Leontiev). The single spiritual archetype of humanity shines with different facets of its national cultures, through each of which it is seen in its entirety but in a specific way, and the more facets it has, the richer is the spectrum of the spiritual content of the archetype. The real unity of peoples is not in slogans and ideologies. It finds itself through the creation of common spiritual values (Chinghiz Aitmatov). The universality cannot contradict the nationality because it is its highest blossom in its essence and truth. Therefore, it is possible to express a paradoxical thought at first glance: universality is the core of nationality. That is why there is no need to give up anything of one's own, native, to become closer to everyone. The truth is not in rootless cosmopolitanism, nor nationalism. It is in the "golden mean," and the writer-thinker sought to express it. Developing moral consciousness passes through the necessary stages of its ascent, which cannot be seized, but may only include everything from individualistic selfishness to family, tribe, people, and nation, and finally, humanity.

\section{References}

[1] Maslin MA. Unity and Diversity of Russian philosophy. In: Russian Philosophy: Encyclopedia. Under General Editorship of MA Maslin. Moscow: Terra-Knigovek; 2014. (In Russian).

[2] Vysheslavtsev BP. The Concept of Eternal in Russian Philosophy. In: Vysheslavtsev BP. Ethics of the Transformed Eros. Moscow: Republic; 1994. P. 154-350. (In Russian). 
[3] Chistyakova OV. Religious Anthropology of Eastern (Greek-Byzantine) Patristics. European Journal of Science and Theology. December 2019;15(6): 145-155.

[4] Dostoevsky FM. Complete Collected Works in 30 Vols. Leningrad: "Science"; 1972-1990. (In Russian).

[5] Schmemann A. Spiritual Destinies of Russia. Fundamentals of Russian culture. Moscow: PSTGU Publishing House; 2017. (In Russian).

[6] Berdyaev NA. Alexei Khomyakov. Tomsk: "Vodoley" Publishing House; 1996. (In Russian).

[7] Florovsky GV. Blessedness of Suffering Love. In: From the Past of Russian Thought. Moscow; 1998. (In Russian).

[8] Gromov MN. Typology of Russian Philosophy. In: History of Philosophy. Moscow: "The Phenomenology-Hermeneutics" 2001. P. 10-43. (In Russian).

[9] Berdyaev NA. Spirits of the Russian Revolution. In: From the Depth: Collection of articles about the Russian Revolution. Moscow: Lomonosov Moscow State University Publishing House; 1990. P. 55-89. (In Russian).

[10] Salvestroni S. The Biblical and Pious Sources of Dostoevsky's Novels. St. Petersburg: Academic Project; 2001. (In Russian).

[11] Zakharov VN. Christian Realism in Russian Literature. In: Gospel Text in Russian Literature of the $18^{\text {th }}-20^{\text {th }}$ centuries... Vol. 3. Petrozavodsk: Petrozavodsk University Publishing House; 2001. P. 5-20. (In Russian).

[12] Bogdanova OA. Under the Dostoevsky Constellation. Moscow; 2008. (In Russian).

[13] Zenkovsky VV. Russian Thinkers' Criticism of European Culture. In: Zenkovsky VV. Russian Thinkers and Europe. Moscow: Respublika; 1997. (In Russian).

[14] Semushkin AV, Kirabaev NS. A.S. Pushkin and Religion. In: A.S. Pushkin and Contemporaneity (to the Poet's 200 th Anniversary): Reports and Messages. Moscow: RUDN University Publishing House; 1999. P. 8-11. (In Russian).

[15] Serbinenko VV. F.M. Dostoevsky on Metaphysics of National Being. In: A.S. Pushkin and Contemporaneity. Moscow; 1999. P. 30-34. (In Russian).

[16] Gulyga AV. Russian Idea and its Creators. Moscow: Soratnik; 1995. (In Russian).

\title{
About the author:
}

Nizhnikov Sergei A. - CSc in Philosophy, Professor, Department of History of Philosophy, RUDN University, Moscow, Russia (e-mail: nizhnikov_sa@rudn.ru).

\section{«Русская идея» Ф.М. Достоевского: от почвенничества к универсализму}

\author{
С.А. Нижников \\ Российский университет дружбы народов, \\ Российская Федерация, 117198, Москва, ул. Миклухо-Маклая, 6, \\ nizhnikov_sa@rudn.ru
}

\begin{abstract}
Аннотация. Раскрываются основные черты творчества Ф.М. Достоевского, его значимость для отечественной и мировой философии. Анализируется понятие «русской идеи», впервые введенного писателем и ставшего предметом изучения в последующей истории русской философии. Вскрывается полемика, возникшая по поводу характеристики почвенничества Достоевского и трактовки им русской идеи в «Очерке о Пушкине»
\end{abstract}


и последующих комментариев в «Дневнике писателя». Автор приходит к выводу, что писатель преодолевает ограниченность почвеннической идеологии, восходя к универсализму. Всечеловеческое у него носит не безродный космополитический характер, а рождается из расцвета национального. Вместе с тем оно не является механическим набором определенных идей или произведений, но представляет сущность каждого из них. Многообразие украшает истину, а национальное разнообразие - человечество. Действительное единство народов не в лозунгах и идеологиях, оно обретается созиданием общих духовных ценностей. Всечеловеческое в этой трактовке, по своей сути и в своей истине, не может противоречить национальному, так как является высшим его расцветом. Лишь развивая национальную культуру, можно приблизиться к всечеловеческому, и это единственно реальное и содержательное его раскрытие, к которому и шла философская мысль в России в лице Достоевского. Истина не в беспочвенном космополитизме, и не в национализме, ее «золотую середину», на наш взгляд, и стремился выразить писательмыслитель.

Ключевые слова: Достоевский, русская идея, почвенничество, универсализм, антропология исихазма, всечеловеческое, национальное

Информация о финансировании и благодарности. Исследование выполнено при финансовой поддержке РФФИ и Министерства по науке и технологиям Тайваня в рамках научного проекта 20-511-S52002 MHT_а «Философия человека как проблема междисциплинарных исследований».

\section{История статьи:}

Статья поступила 05.08.2020

Статья принята к публикации 06.10.2020

Для цитирования: Nizhnikov S.A. "Russian Idea" of F.M. Dostoevsky: from Soilness to Universality // Вестник Российского университета дружбы народов. Серия: Философия. 2021. T. 25. № 1. C. 15-24. DOI: 10.22363/2313-2302-2021-25-1-15-24

\section{Список литературы}

[1] Маслин М.А. Единство и многообразие русской философии // Русская философия: Энциклопедия / Под общей ред. М.А. Маслина. М. : Терра-Книговек, 2014.

[2] Вышеславцев Б.П. Вечное в русской философии // Вышеславцев Б.П. Этика преображенного Эроса. М. : Республика, 1994. С. 154-350.

[3] Chistyakova O.V. Religious Anthropology of Eastern (Greek-Byzantine) Patristics // European Journal of Science and Theology. December 2019. Vol. 15. № 6. P. 145-155.

[4] Достоевский Ф.М. Полн. собр. соч.: в 30 т. Л. : Наука, 1972-1990.

[5] Шмеман А. Духовные судьбы России // Основы русской культуры. М. : Изд-во ПСТГУ, 2017.

[6] Бердяев Н.А. Алексей Степанович Хомяков. Томск : Изд-во «Водолей», 1996.

[7] Флоровский Г.В. Блаженство страждущей любви // Из прошлого русской мысли. М. : 1998.

[8] Громов М.Н. Типология русской философии // История философии. М. : Феноменология-Герменевтика, 2001. С. 10-43.

[9] Бердяев Н.А. Духи русской революции // Из глубины: Сборник статей о русской революции. М. : Изд-во Моск. ун-та, 1990. С. 55-89. 
[10] Сальвестрони С. Библейские и святоотеческие источники романов Достоевского. СПб. : Академический проект, 2001.

[11] Захаров B.Н. Христианский реализм в русской литературе // Евангельский текст в русской литературе XVIII - XX веков... Вып. 3. Петрозаводск : изд-во Петроз. $\mathrm{Y}_{\mathrm{H}-\mathrm{Ta}}$ 2001. С. 5-20.

[12] Богданова О.А. Под созвездием Достоевского. М. : Изд-во Кулагиной, 2008.

[13] Зеньковский B.B. Критика европейской культуры у русских мыслителей // Русские мыслители и Европа. М. : Республика, 1997.

[14] Семушкин А.В., Кирабаев Н.С. А.С. Пушкин и религия // А.С. Пушкин и восременность (к 200-летию со дня рождения поэта): Доклады и сообщения. М. : Изд-во РУДН, 1999. С. 8-11.

[15] Сербиненко В.В. Ф.М. Достоевский о метафизике национального бытия // А.С. Пушкин и современность. М., 1999. С. 30-34.

[16] Гульга А.В. Русская идея и ее творцы. М. : Соратник, 1995.

\section{Сведения об авторе:}

Нижников Сергей Анатольевич - доктор философских наук, профессор, кафедра истории философии, Российский университет дружбы народов, Москва, Россия (e-mail: nizhnikov_sa@rudn.ru). 